\title{
The Prosthetic Influence and Biomechanics on Peri-Implant Strain: a Systematic Literature Review of Finite Element Studies
}

\author{
Julius Maminskas ${ }^{1}$, Algirdas Puisys ${ }^{2}$, Ritva Kuoppala ${ }^{3}$, Aune Raustia ${ }^{3}$, Gintaras Juodzbalys ${ }^{4}$ \\ ${ }^{1}$ Department of Prosthodontics, Lithuanian Universty of Health Sciences, Kaunas, Lithuania. \\ ${ }^{2}$ Vilnius Implantology Center, Vilnius, Lithuania. \\ ${ }^{3}$ Prosthetic Dentistry and Stomatognathic Physiology, Research Unit of Oral Health Sciences, Faculty of Medicine, \\ University of Oulu, Medical Research Center Oulu, Oulu University Hospital and University of Oulu, Finland. \\ ${ }^{4}$ Department of Maxillofacial Surgery, Lithuanian Universty of Health Sciences, Kaunas, Lithuania.
}

\author{
Corresponding Author: \\ Julius Maminskas \\ Kursiu 56-20, 48133, Kaunas \\ Lithuania \\ E-mail: j.maminskas@gmail.com
}

\begin{abstract}
Objectives: To systematically review risks of mechanical impact on peri-implant strain and prosthetic influence on stability across finite element studies.

Material and Methods: An online literature search was performed on MEDLINE and EMBASE databases published between 2011 and 2016. Following keywords tiered screening and selection of the title, abstract and full-text were performed. Studies of finite element analysis (FEA) were considered for inclusion that were written in English and revealed stress concentrations or strain at peri-implant bone level.

Results: There were included 20 FEA studies in total. Data were organized according to the following topics: bone layers, type of bone, osseointegration level, bone level, design of implant, diameter and length of implant, implant-abutment connection, type of supra-construction, loading axis, measurement units. The stress or strain at implant-bone contact was measured over all studies and numerical values estimated. Risks of overloading were accented as non-axial loading, misfits, cantilevers and the stability of peri-implant bone was related with the usage of platform switch connection of abutment.

Conclusions: Peri-implant area could be affected by non-axial loading, cantilever prosthetic elements, crown/implant ratio, type of implant-abutment connection, misfits, properties of restoration materials and antagonistic tooth. The heterogeneity of finite element analysis studies limits systematization of data. Results of these studies are comparable with other findings of $i n$ vitro, in vivo, prospective and retrospective studies.
\end{abstract}

Keywords: dental implants; dental stress analysis; finite element analysis; peri-implantitis; treatment failure.

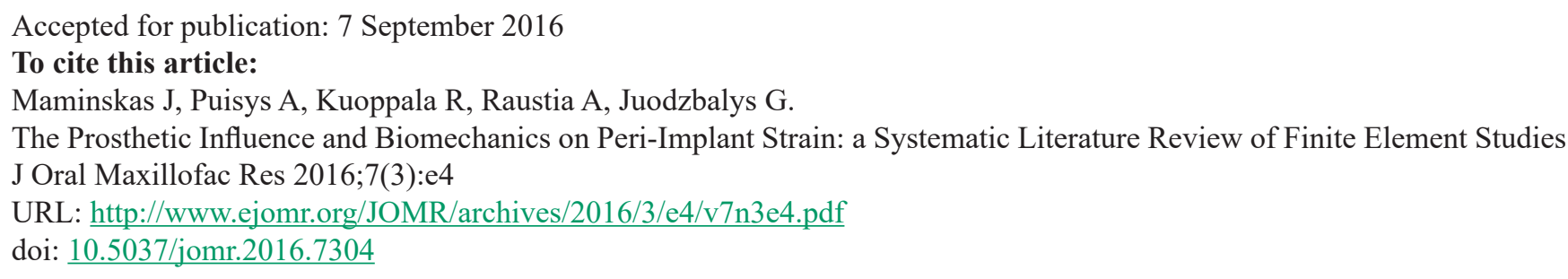




\section{INTRODUCTION}

Contemporary restorations of dental defects with implants are widely applicable, clinically prospective and comfortable treatment method. Although it is important to realize that this method, as all other restorative procedures, is aimed not to change the tooth but exactly restore what has been lost in biological and mechanical aspects $[1,2]$.

An implant success rate is a numerical quantitative expression, which values the success of the implant as a matter of persistence until its fatal loss. This rate reaches $95 \%$ and is based on the osseointegration of the implant [ $\underline{3}$ ]. If the osseointegration does not occur, the implant will be rejected and will not have a successful outcome because of early complications. There are two types of failures: early complication, which occur before the prosthetics and late complications after osseointegration and restoration $[\underline{2,4-8}]$. It means that all $95 \%$ of successful implants still have risks of late failures, which are related with longevity and quality of treatment. Under functional loading condition physiologically we can expect $1-1.5 \mathrm{~mm}$ bone loss throughout the first year and $<0.2 \mathrm{~mm}$ every following year $[\underline{8}, 9]$. This process could be accelerated by mechanical, chemical and biological factors. With lack of attention and control, this physiological process may turn into a pathological inflammation of peri-implant soft tissues as periimplant mucositis or its later form: peri-implantitis.

Despite high implant survival rate, epidemiological studies and clinicians insufficiently paying attention to the quality factor and sustainability of our final restoration. However, there should be understood that implants cannot sufficiently replace natural teeth despite their survival rates [2].

Some of the main reasons for late implant failures can be bacterial factors, host health conditions (diabetes mellitus and bisphosphonates), smoking, overloading and iatrogenic factors [9-11]. Overloading and iatrogenic risk factors are closely related with prosthetic solutions.

Major debates and the absence of consensus prevail especially due to overloading effect on implant complications. The intact root of the tooth is covered by periodontium and has 25 to $100 \mu \mathrm{m}$ micromovements on axial direction. In comparison, osseointegrated dental implants can move just 3 to $5 \mu \mathrm{m}$ at the same axis $[\underline{12}, \underline{13}]$. Tooth mobility is determined by deformation of periodontal ligaments while implant mobility is determined by limited deformation of the bone. In a micro-movement like this, the periodontal ligament works as a damper and can reduce the effect of the stress on surrounding structures. Moreover, periodontium could adjust the load because of proprioceptive sensors. According to mechanostat theory by Frost [14], both bone growth and resorption are closely dependent on affecting mechanical forces. So the osseointegrated implant can be overloaded and not survive due to loading [15]. However, there are no clear guidelines: how much functional and para-functional loading can be injurious for dental implant, what mechanical factors can decrease load effect for such kind of restorations and what should be avoided. These are still not reviewed in older publications.

The aim of this review is to find out risks of mechanical impacts of peri-implant bone loss and prosthetic influence on bone stability.

\section{MATERIAL AND METHODS Protocol and registration}

The review was registered on the international prospective register of systematic reviews PROSPERO. Registration number: CRD42016037224. The design of data search, analysis and selection criteria was described in advance. This protocol could be found in PROSPERO register:

http://www.crd.york.ac.uk/PROSPERO/display record.asp?ID=CRD42016037224

This review was performed following PRISMA statements (Preferred Reporting Item for Systematic Review and Meta-Analyses) [16].

\section{Types of publications}

The review included publications in English, which were published from January 2011 till April 2016. Letters, editorials, literature reviews, $\mathrm{PhD}$ theses and abstracts were excluded.

\section{Types of studies}

The selection of studies consists of randomized control trials, cohort studies, case-control studies, case reports, animal and in vitro studies.

\section{Information sources and search}

A literature search was performed of two databases - MEDLINE (PubMed) and EMBASE websites. The specific keywords were selected on purpose to establish a maximal informative and an accurate search. Keywords were as follows: "absorbing", 
"bone", "damping", "dental implant", "disintegration", "loss", "occlusal”, "overloading", "periimplant", "shock", "strain", "stress". According to these, the search was performed on PubMed and EMBASE search systems: "dental" AND "implant" AND ("overloading" OR "stress" OR "shock" OR "strain") AND (("bone" AND "loss") OR "disintegration" OR "damping" OR “absorbing”).

\section{Selection of studies}

Two reviewers independently screened the title and abstract of articles derived from this broad search. After primary screening decisions of both reviewers were compared and discussed. The third experienced reviewer accomplished a secondary screening for those cases where the disagreement was.

\section{Inclusion criteria}

The inclusion of articles was done according to: the description of the usage of dental implants, the estimation of implant loading, the load transmission and distribution over peri-implant bone or bone level changes. Fixed prosthetic treatment and functional loading or over-loading should be applied in studies.

\section{Exclusion criteria}

In order to review the latest data, the studies over 5 years old were not included. 3 studies were excluded because they lacked an abstract. Studies which evaluated removable dentures on implants were excluded. The biomechanical functionality of such prostheses is different than fixed. Also, studies that analyse the effect of masticatory forces in restoration level only (crown, abutment, screw) without changes in the bone level were excluded.

\section{Data extraction}

The selected studies were divided into groups according to the type of the study: experimental in vitro, experimental in vivo and clinical. Data of experimental finite element analysis (FEA) studies were systematized in assessing load vector and value, stress and strain in peri-implant bone, implant length, diameter, bone layers, type of bone, bone level, osseointegration level, implant design, type of implant-abutment connection, restoration (Table 1).

\section{Data items}

Data were collected from the included FEA studies and arranged in the following fields:
"Bone layers" - shows types of applied bone layers;

- "Type of bone" - describes the density of bone;

- "Osseointegration level" - characterizes the conditions of implant osseointegration;

- "Bone level" - describes the depth of implant position;

- "Design of implant" - describes the shape of implant model;

- "Diameter of implant" - describes diameter dimension;

- "Length of implant" - describes length dimension;

- "Implant-abutment connection" - shows type of connection (platform switch or non-platform switch);

- "Type of supra-construction" - description of prosthesis;

- "Axial load" - strength value in an axial direction;

- "Oblique load" - strength value in an oblique direction;

- "Lateral load" - strength value in a lateral direction;

- "Stress/strain units" - measuring units.

\section{Assessment of methodological quality}

The intrinsic methodological and lacks of design were independently screened by two reviewers. The qualitative assessment was accomplished for each of elected study and their risk of bias was evaluated according to the Cochrane library [17].

\section{RESULTS \\ Study selection}

The search on MEDLINE (PubMed) and EMBASE databases resulted in 533 publications. Following inclusion/exclusion criteria 42 articles were selected and fully read. They were grouped according to the type of the study: 20 - in vitro FEA; 8 - in vitro (tests); 5 - in vivo; 3 - prospective, 6 - retrospective. The distribution of publications shows the prevalence of virtual FEA mechanistic studies. With the intention of achieving methodical homogeneity, FEA studies were selected for a detailed analysis and comparison of results and values. All FEA studies $(n=20)$ were involved in data analysis (Figure 1).

\section{Study characteristics}

The analysis of articles, which describes the FEA study, illustrates that both conditions and the obtained data are heterogeneous (Table 1). 
Table 1. Collected data

\begin{tabular}{|c|c|c|c|c|c|c|c|c|c|c|c|c|c|c|}
\hline Study & $\begin{array}{c}\text { Year of } \\
\text { publication }\end{array}$ & $\begin{array}{l}\text { Bone } \\
\text { layers }\end{array}$ & $\begin{array}{c}\text { Type of } \\
\text { bone }\end{array}$ & $\begin{array}{c}\text { Osseo } \\
\text { integration level }\end{array}$ & $\begin{array}{l}\text { Bone } \\
\text { level } \\
(\mathrm{mm})\end{array}$ & $\begin{array}{c}\text { Design of } \\
\text { implant }\end{array}$ & $\begin{array}{c}\text { Diameter of } \\
\text { implant } \\
(\mathrm{mm})\end{array}$ & \begin{tabular}{|c|}
$\begin{array}{c}\text { Length of } \\
\text { implant } \\
(\mathrm{mm})\end{array}$ \\
\end{tabular} & \begin{tabular}{|c|} 
Implant- \\
abutment \\
connection
\end{tabular} & $\begin{array}{c}\text { Type of } \\
\text { supra } \\
\text { construction }\end{array}$ & Axial load & $\begin{array}{l}\text { Oblique } \\
\text { load }\end{array}$ & $\begin{array}{c}\text { Lateral } \\
\text { load }\end{array}$ & $\begin{array}{c}\text { Stress/strain } \\
\text { units }\end{array}$ \\
\hline Jimbo et al. [18] & 2013 & $\mathrm{C}$ & ND & Medium/partial & ND & Cylindrical & ND & ND & PS & NA & $250 \mathrm{~N} ; 200 \mathrm{~N}$ & NA & NA & $\mathrm{MPa}$ \\
\hline Aguirrebeitia et al. [19] & 2013 & $\mathrm{C}$ & ND & High/full & ND & Threaded & 4.5 & 9 & PS & Abutment & NA & $200 \mathrm{~N} ; 30^{\circ}$ & NA & von Mises MPa \\
\hline Bouazza-Juanes et al. [20] & 2015 & $\mathrm{C}+\mathrm{T}$ & ND & High/full & 0 & Threaded & 4.1 & 11 & NPS; PS & NA & $100 \mathrm{~N}$ & $100 \mathrm{~N} ; 15^{\circ}$ & NA & von Mises MPa \\
\hline Sahabi et al. [21] & 2013 & $\mathrm{C}+\mathrm{T}$ & ND & High/full & 0 & Threaded & $3.5 ; 4 ; 4.8 ; 5$ & $11 ; 11.5$ & NPS; PS & NA & $100 \mathrm{~N}$ & $100 \mathrm{~N} ; 15^{\circ}$ & NA & von Mises $\mathrm{MPa}$ \\
\hline Paul et al. [22] & 2013 & $\mathrm{C}+\mathrm{T}$ & D3 & Medium/partial & 0 & Threaded & 4.3 & 13 & NPS; PS & NA & $\begin{array}{c}50 \mathrm{~N} ; 150 \mathrm{~N} \\
250 \mathrm{~N}\end{array}$ & $\begin{array}{c}50 \mathrm{~N} ; 150 \mathrm{~N} \\
250 \mathrm{~N} ; 45^{\circ}\end{array}$ & NA & $\mu$ Strain \\
\hline Martini et al. [23] & 2012 & $\mathrm{C}+\mathrm{T}$ & ND & High/full & ND & Threaded & 5 & 13 & PS & Ceramic & $100 \mathrm{~N}$ & $100 \mathrm{~N} ; 45^{\circ}$ & NA & $\mathrm{MPa}$ \\
\hline Vidya et al. [24] & 2014 & $\mathrm{C}+\mathrm{T}$ & D2 & High/full & 0 & ND & 4.3 & $6 ; 8 ; 10 ; 13$ & One-piece & NA & $250 \mathrm{~N}$ & ND & $100 \mathrm{~N}$ & von Mises MPa \\
\hline I-Chiang et al. [25] & 2014 & $\mathrm{C}+\mathrm{T}$ & D4 & Absent; high/full & 0.5 & Threaded & $3.7 ; 4 ; 4.1$ & 11 & NA & NA & $300 \mathrm{~N} ; 460 \mathrm{~N}$ & $150 \mathrm{~N} ; 60^{\circ}$ & $75 \mathrm{~N}$ & von Mises MPa \\
\hline Santiago Junior et al. [26] & 2013 & $\mathrm{C}+\mathrm{T}$ & D3 & ND & 0 & Threaded & $3.75 ; 5$ & 10 & NPS & $\begin{array}{c}\text { Ceramic; } \\
\text { composite; } \\
\text { acrylic; metal }\end{array}$ & $200 \mathrm{~N}$ & $100 \mathrm{~N} ; \mathrm{ND}$ & NA & $\begin{array}{c}\mathrm{MPa} \\
\text { von Mises MPa }\end{array}$ \\
\hline Savadi et al. [27] & 2011 & $\mathrm{C}+\mathrm{T}$ & ND & ND & ND & Cylindrical & 4.1 & 12 & ND & NA & $100 \mathrm{~N}$ & NA & $50 \mathrm{~N}$ & von Mises MPa \\
\hline Chou I-C et al. [28] & 2014 & $\mathrm{C}+\mathrm{T}$ & D4 & Absent; high/full & 0 & Threaded & $3.9 ; 4 ; 4.1$ & 11 & NA & NA & $500 \mathrm{~N}$ & NA & NA & von Mises MPa \\
\hline Demenko et al. [29] & 2014 & $\mathrm{C}+\mathrm{T}$ & $\begin{array}{l}\text { D1; D2; } \\
\text { D3; D4 }\end{array}$ & High/full & ND & Cylindrical & $\begin{array}{c}3 ; 3.5 ; 4 \\
4.5 ; 5\end{array}$ & $8 ; 10 ; 12 ; 14$ & NA & NA & NA & $118.2 \mathrm{~N} ; 75^{\circ}$ & NA & von Mises MPa \\
\hline Bölükbaş1 et al. [30] & 2015 & $\mathrm{C}+\mathrm{T}$ & D3 & ND & ND & ND & $3.3 ; 4.1$ & 12 & PS & Metal-ceramic & NA & $100 \mathrm{~N} ; 45^{\circ}$ & NA & $\mu$ Strain \\
\hline Ormianer et al. [31] & 2012 & $\mathrm{C}+\mathrm{T}$ & ND & $\begin{array}{c}\text { Medium/partial; } \\
\text { high/full }\end{array}$ & ND & Threaded & $3.7 ; 4.7 ; 6$ & ND & ND & Titanium coping & NA & $222 \mathrm{~N} ; 30^{\circ}$ & NA & von Mises MPa \\
\hline Xia et al. [33] & 2013 & $\mathrm{C}+\mathrm{T}$ & ND & High/full & $0 ;-2$ & ND & ND & ND & NPS; PS & Metal & $200 \mathrm{~N}$ & $200 \mathrm{~N} ; \mathrm{ND}$ & NA & $\mathrm{MPa}$ \\
\hline Sotto-Maior et al. [34] & 2012 & $\mathrm{C}+\mathrm{T}$ & ND & ND & ND & Threaded & 5 & 7 & NPS & $\begin{array}{c}\text { Gold-ceramic; } \\
\text { zirconium-ceramic }\end{array}$ & $200 \mathrm{~N}$ & NA & NA & von Mises MPa \\
\hline Romeed et al. [36] & 2013 & $\mathrm{C}+\mathrm{T}$ & ND & ND & \begin{tabular}{|l|}
$-4.5 ;-3 ;$ \\
$-1.5 ; 0$
\end{tabular} & ND & 3.5 & 13 & ND & ND & ND & ND & ND & von Mises $\mathrm{MPa}$ \\
\hline Arun Kumar et al. [38] & 2013 & $\mathrm{C}+\mathrm{T}$ & $\begin{array}{l}\text { D1; D2; } \\
\text { D3; D4 }\end{array}$ & High/full & 0 & Threaded & 4.3 & 10 & NPS & NA & $178 \mathrm{~N}$ & NA & NA & von Mises MPa \\
\hline Alvarez-Arenal et al. [63] & 2014 & $\mathrm{C}+\mathrm{T}$ & D2 & High/full & ND & Threaded & ND & ND & ND & Metal-ceramic & NA & $\begin{array}{c}249.9 \mathrm{~N} \\
6-35^{\circ}\end{array}$ & NA & von Mises MPa \\
\hline Kurniawan et al. [64] & 2012 & $\mathrm{C}+\mathrm{T}$ & \begin{tabular}{|c|} 
D2; D3; \\
D4
\end{tabular} & $\begin{array}{c}\text { Low; medium/ } \\
\text { partial; high/full }\end{array}$ & 0 & Threaded & 3.8 & ND & ND & NA & $380 \mathrm{~N}$ & NA & NA & $\mathrm{MPa} ; \mu$ Strain \\
\hline
\end{tabular}

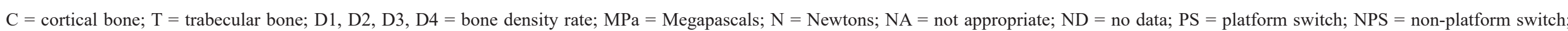
$\mu$ Strain $=$ a common engineering unit measuring strain. 


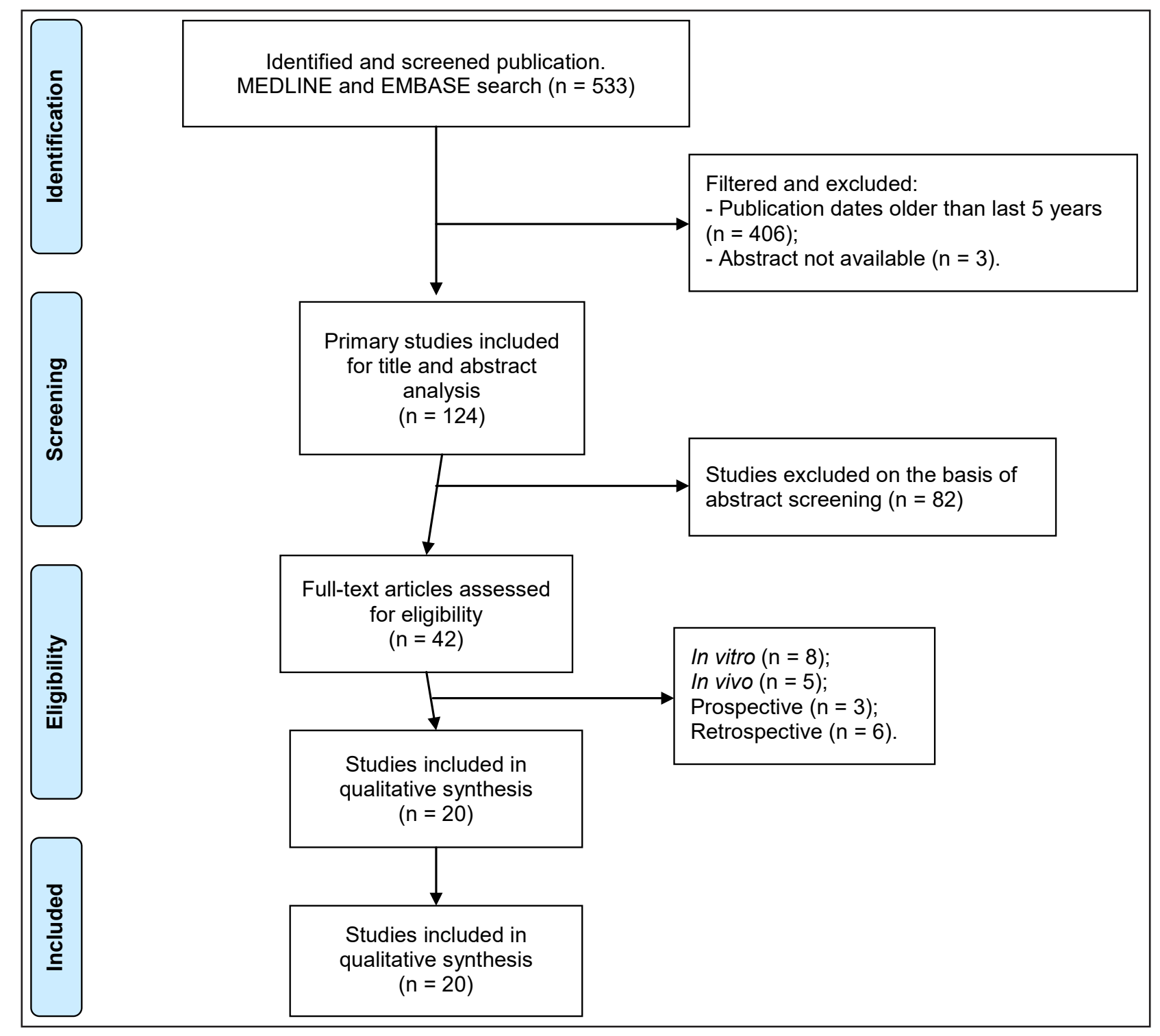

Figure 1. Procedural flow of the literature search and selection process.

According to methods, studies differ on the different simulated conditions:

1. A different bone base. Mainly, double layered (cortical + trabecular) bone model was applied and only a few models were single layered $[\underline{18}, \underline{19}]$. The authors programmed various bone types (D1 - D4) and some were evaluating stress distribution on bone following density. The shape of the bone model had variations too. For example, it could be programmed as a periimplant cylinder, as a section of the jaw or a full dental arch. Some authors provided a real scanned situation.

2. A different osseointegration. In reality, implant is not fused with bone absolutely. There is no consensus for osseointegration conditions on FEA. Some referred to it as an ideal for simplicity $(100 \%$ integration) and others as a partial osseointegration for more realistic model.
3. Variation of implants design. There were different selection of implant length, diameter, thread and other properties in the studies. There were studies, which defined a cohort according to the geometry.

4. Variation of the implant-abutment connection. Some of the investigations were carried out without a reference of the implant-abutment connection or completely without it. Others defined a cohort according to the connection type.

5. Different restorative solutions. The selection of restorative materials, layers, bonding conditions and shapes varied. Also, there were studies in which the investigation was performed only at implant-abutment model.

6. Different loading directions. Variable loading vectors were distributed as follows: axial, oblique and lateral. The angle of oblique load was a variable too. Some studies analysed stress distribution depending on load direction 
but mostly dominated free of choice.

7. Loading variation. The loading conditions are simulated not only at different vectors but also at different loads, which were used from 50 to $500 \mathrm{~N}$.

8. Different outcome units. The gained data were presented in different units of measurement. The dominant measuring of stress was expressed in von Mises $\mathrm{MPa}$, but studies with tangential stress were measured in MPa or strain in $\mu$ Strain.

9. There were certainly other differences among models that were less emphasized.

10. The impact of loading resulted in stress or strain at the implant-bone interface was described in all 20 publications. Mainly there were stress dependence on the force acting axis [20-28] and all authors assured that non-axial loading increased peri-implant stress. Also, implant design characteristics were described as factors causing the stress. The alteration of stress was related with implant length $[21,24,29]$, width $[21,25,26,28-31]$, macro-relief as thread $[\underline{28}, \underline{32}]$, and micro-relief as porosity [27]. Some of the articles emphasized that stress changes were caused by platform switching connection $[\underline{20-22,33]}$. The influence of abutment-implant connection was also described by another two articles, who revealed impact of inaccuracy at this interface $[18,19]$. Prosthetic related factors as crown/implant (C/I) ratio [34] and restorative materials $[\underline{26}, \underline{34}]$ were also analysed.

\section{Quality assessment}

All the selected studies were assessed for their risk of bias according to the Cochrane library [17]. The sequence generation was not explained and moreover limited. The included studies did not report it. The sequence generation could be debatable for in vitro or perhaps impossible, especially for FEA. Evaluation of allocation concealment and blinding of participants and outcomes of in vitro studies was confirmed severe and not appropriate. The incomplete outcome data was not explained in most cases and assessment "unclear" means that no missing data was reported (Table 2).

\section{Synthesis of results}

Due to the study design and conditions, heterogeneity of outcomes may not achieve a comparison of results and statistical analysis. The collected data are ineligible for meta-analysis and/or systematic review.

Table 2. Bias summary

\begin{tabular}{l|c|c|c|c|c|c}
\hline \multicolumn{1}{|c|}{ Study } & $\begin{array}{c}\text { Adequate } \\
\text { sequence } \\
\text { generation? }\end{array}$ & $\begin{array}{c}\text { Allocation } \\
\text { concealment? }\end{array}$ & $\begin{array}{c}\text { Blinding of } \\
\text { outcome } \\
\text { assessment? }\end{array}$ & $\begin{array}{c}\text { Incomplete } \\
\text { outcome data } \\
\text { addressed? }\end{array}$ & $\begin{array}{c}\text { Free of } \\
\text { selective } \\
\text { reporting? }\end{array}$ & $\begin{array}{c}\text { Free of } \\
\text { other bias? }\end{array}$ \\
\hline Jimbo et al. [18] & Unclear & NA & NA & Unclear & No & Yes \\
\hline Aguirrebeitia et al. [19] & Unclear & NA & NA & Unclear & Yes & Yes \\
\hline Bouazza-Juanes et al. [20] & Unclear & NA & NA & Unclear & Yes & Yes \\
\hline Sahabi et al. [21] & Unclear & NA & NA & Unclear & Yes & Yes \\
\hline Paul et al. [22] & Unclear & NA & NA & Unclear & Unclear & Yes \\
\hline Martini et al. [23] & Unclear & NA & NA & Unclear & Yes & Yes \\
\hline Vidya et al. [24] & Unclear & NA & NA & Unclear & Yes & Unclear \\
\hline I-Chiang et al. [25] & Unclear & NA & NA & Unclear & Yes & Yes \\
\hline Santiago Junior et al. [26] & Unclear & NA & NA & Unclear & Unclear & Unclear \\
\hline Savadi et al. [27] & Unclear & NA & NA & No & Unclear & Yes \\
\hline Chou I-C et al. [28] & Unclear & NA & NA & Unclear & Unclear & Yes \\
\hline Demenko et al. [29] & Unclear & NA & NA & Unclear & Yes & Yes \\
\hline Bölükbaş1 et al. [30] & Unclear & NA & NA & Unclear & Yes & Yes \\
\hline Ormianer et al. [31] & Unclear & NA & NA & No & Unclear & Unclear \\
\hline Xia et al. [33] & Unclear & NA & NA & Unclear & Yes & Yes \\
\hline Sotto-Maior et al. [34] & Unclear & NA & NA & Unclear & Yes & Yes \\
\hline Romeed et al. [36] & Unclear & NA & NA & No & Unclear & Yes \\
\hline Arun Kumar et al. [38] & Unclear & NA & NA & Unclear & Yes & Yes \\
\hline Alvarez-Arenal et al. [63] & Unclear & NA & NA & Unclear & Unclear & Unclear \\
\hline Kurniawan et al. [64] & Unclear & NA & NA & Unclear & Yes & Yes \\
\hline
\end{tabular}

$\mathrm{NA}=$ not appropriate 


\section{DISCUSSION}

This review was performed with an aim to systematically review risks of mechanical impact on peri-implant strain and prosthetic influence for stability across FEA studies. Despite the heterogeneity between the FEA studies, the established trends correlate with other in vitro, in vivo, prospective and retrospective studies from the same search.

According to Newton's third law it is undisputed that chewing forces are transmitted to restoration and these forces do not decrease but transform into energy, which is distributed in certain amounts through the restoration-implant complex. Energy could be distributed into restorative materials, cement layer, abutment, screw, implants and peri-implant bone. According to reviewed studies, an overloading of peri-implant bone could be determined by several factors.

FEA studies have shown dependence between stress distribution and loading direction [35]. Assessing the effect of the axial force, was detected the distribution of uniform stress in peri-implant bone without concentrations in a specific surface area of the implant $[24,25,27,28,36]$. These FEA findings are close to results of in vivo studies. Also, dependence on axial displacement of the force direction was found [37]. The axial force of $30 \mathrm{~N}$ generated much higher displacement than lateral. Therefore, the damping behaviour is more expected under the axial load transmission.

The non-axial loading of the implant increased the stress concentrations in peri-implant bone because of bending $[\underline{20}, \underline{21}, \underline{23}, \underline{26}, \underline{38}]$. It is important to understand, that the axis of rotation locates at the top of the bone $[\underline{36}, 39]$. In FEA models under load of $100 \mathrm{~N}$ without any changes of other conditions except of loading direction (axial vs. oblique), the stress increased and its trend of concentration was revealed under oblique loading $[\underline{20}, 21,23]$. The stress increased specifically around the neck of the implant on cortical bone. Angled abutments created the same effect because they shifted the load from the implant axis $[\underline{23}, \underline{38}]$. Without changes of load direction following the increased abutment angulation from 0 to $15^{\circ}$, stress concentrations increased in cortical periimplant bone. Consequently, the oblique load creates a bending effect, which affects the bone, especially around the rotation area but the different mechanical properties of bone layers determine different displacement of the implant body.

Other parameters of restorations such as cantilevers and $\mathrm{C} / \mathrm{I}$ ratio could increase bending of the implant and stress or strain in the bone. Retrospective study shows the relation between bone loss and cantilevers [40]. The behaviour of different sized restorations was compared: single-unit, fixed partial, fixed full. Another retrospective study did not find significant bone loss around implant when distal cantilevers were constructed with full arch prosthesis [41]. So the number of implants could create a counterpoise and reduce the bending effect of cantilevers. The similar bending effect could be caused by the extended width of the implant crown. However, the study did not find an influence between the width of the crown and periimplant bone loss [42]. Related FEA studies were not found.

Sotto-Maior et al. [34] performed an FEA study, in which the influence of different $\mathrm{C} / \mathrm{I}$ ratio to stress distribution was investigated. $22.47 \%$ of cortical bone stress depended on $\mathrm{C} / \mathrm{I}$ ratio. The stress increased with an increase of $\mathrm{C} / \mathrm{I}$ ratio. When $\mathrm{C} / \mathrm{I}=2.5$ stress concentrations increased more than twice [34]. The dependence between peri-implant bone loss and C/I ratio was confirmed in prospective clinical studies $[\underline{43}, \underline{44}]$. Otherwise, C/I ratio depends not only on crown length, but also on implant length. This supports the FEA study with the conclusion that short implants create higher stress at peri-implant cortical bone [45].

The shape of the implant could affect the stress distribution around the implant surface. According to FEA results, as the diameter of the implant decreased, the stress concentration increased $[26,31,45]$. Also, stress distribution depends on surface design $[46,47]$ and thread configuration [르]

Abutment connection design also affects the stress concentration in peri-implant bone. The connection area could provide a stress-damping effect $[\underline{48}, \underline{49}]$. All studies comparing the effectiveness of conventional (non-platform switch) and platform switch abutments revealed that platform switch type abutments decreased stress concentrations in peri-implant bone $[20-22,33]$ and its positive effect was higher for cortical bone than trabecular [23]. On the other hand, platform switch reduced stress from the bone, but accelerated on the interface of connection surfaces [21] and that could provoke strain for mechanical parts such as implant, screw and abutment. But we can conclude, that platform switch tends to be a damping element.

The concept of passive fit implies that there was no gap or strain induced by misfit of the framework prior to functional loading [50]. Misfits of prosthetic elements could generate peri-implant stress [18]. This FEA investigated peri-implant stress when theoretical misfit was recorded on implant-abutment level 
and on abutment-crown level. The stress was dependent on misfit. Aguirrebeitia et al. [19] approved similar findings in their study, where misfit of abutment was generated with changing of conical angle of abutment. They detected that discrepancy between contacting surface increased the stress in surrounding bone. The passive fit of implant and related prosthetic components were considered to be very important and its absence was thought to cause complications in biological tissues and mechanical failures [51]. Consequently, imperfections at the connection regions could generate overloading of peri-implant bone as well as in prosthetic parts $[18,19,52]$. It may be worth considering, that analog abutments or bases could cause the similar stress because of unmanaged imperfections.

The influence of restorative materials on stress distribution was not confirmed by FEA $[\underline{26}, \underline{34}]$. However, these results could be due to limitation of finite element models. The loading condition is mostly described as static with linear deformability. Materials with different elastic modulus were perfectly bonded without any displacement freedom [35]. Magne et al. in their in vitro study [53] detected that shockabsorbing capacity of implant restorations depends on damping behaviour of different dental materials under the cyclic loading conditions. The usage of composite materials damping behaviour was growing due to visco-elasticity of such material $[\underline{54,55]}$. Changes could exist in restorative layers but that could not be detected by static linear FEA. If the damping effect of platform switch was detected, elastic prosthetic parts could accelerate the same phenomenon.

Magne et al. [53] described damping behaviour of periodontal ligament and its shock-absorbance. In clinical cases, when an implant restoration had a natural opposite tooth, the periodontal ligament of antagonistic could absorb significant part of the loading energy $[\underline{56}, \underline{57}]$. Authors established $0.2 \mathrm{~mm}$ peri-implant bone loss in cases with natural antagonist and $0.6 \mathrm{~mm}$ bone loss in cases with opposite implant restoration at the same time [56], and concluded, that higher bone level is in cases with opposite natural tooth $[\underline{56}, \underline{57}]$.

Occlusal overloading was said to be the primary cause of biomechanical implant complications [58]. Implant loss because of direct overloading reasons was described in in vivo [59] study with rats and in retrospective study [60]. In vivo based older studies detected that in case of bacterial peri-implant inflammation and overloading could accelerate bone loss [61]. However, we have to agree with Pellegrini et al. [62] review, which stated that the detrimental effect of occlusal overload on bone-implant interface is still a controversial issue. The histological findings found in animal studies might not be straight usable in humans.

\section{CONCLUSIONS}

Peri-implant strain could be generated by non-axial loading, cantilever prosthetic elements, crown/implant ratio, type of implant-abutment connection, misfits, properties of restoration materials and antagonistic tooth. Finite element analysis studies are not erroneous methodically and the results correlate with other experimental and clinical findings. Due to the heterogeneity of finite element analysis studies and expression of their results, it is impossible to perform meta-analysis or systematic reviews.

\section{ACKNOWLEDGMENTS AND DISCLOSURE STATEMENTS}

The authors report no conflicts of interest related to this study.

\section{REFERENCES}

1. Magne P, Douglas WH. Rationalization of esthetic restorative dentistry based on biomimetics. J Esthet Dent. 1999;11(1):515. [Medline: 10337285 ] [doi: $10.1111 / j .1708-8240.1999 . t b 00371 . x]$

2. Schenk RK, Buser D. Osseointegration: a reality. Periodontol 2000. 1998 Jun;17:22-35. Review. [Medline: 10337310] [doi: 10.1111/j.1600-0757.1998.tb00120.x]

3. Giannobile WV, Lang NP. Are Dental Implants a Panacea or Should We Better Strive to Save Teeth? J Dent Res. 2016 Jan;95(1):5-6. [Medline: 26701917] [doi: 10.1177/0022034515618942]

4. Esposito M, Hirsch JM, Lekholm U, Thomsen P. Biological factors contributing to failures of osseointegrated oral implants. (I). Success criteria and epidemiology. Eur J Oral Sci. 1998 Feb;106(1):527-51. [Medline: 9527353] [doi: 10.1046/j.0909-8836..t01-2-.x]

5. Esposito M, Hirsch JM, Lekholm U, Thomsen P. Biological factors contributing to failures of osseointegrated oral implants. (II). Etiopathogenesis. Eur J Oral Sci. 1998 Jun;106(3):721-64. [Medline: 9672097] [doi: 10.1046/j.0909-8836..t01-6-.x] 
6. Anitua E, Orive G, Aguirre JJ, Ardanza B, Andía I. 5-year clinical experience with BTI dental implants: risk factors for implant failure. J Clin Periodontol. 2008 Aug;35(8):724-32. [Medline: 18616758] [doi: 10.1111/j.1600-051X.2008.01248.x]

7. Koldsland OC, Scheie AA, Aass AM. Prevalence of implant loss and the influence of associated factors. J Periodontol. 2009 Jul;80(7):1069-75. [Medline: 19563286] [doi: 10.1902/jop.2009.080594]

8. Sánchez-Pérez A, Moya-Villaescusa MJ, Caffesse RG. Tobacco as a risk factor for survival of dental implants. J Periodontol. 2007 Feb;78(2):351-9. [Medline: 17274726] [doi: 10.1902/jop.2007.060299]

9. Dalago HR, Schuldt Filho G, Rodrigues MA, Renvert S, Bianchini MA. Risk indicators for Peri-implantitis. A crosssectional study with 916 implants. Clin Oral Implants Res. 2016 Jan 11. [Medline: 26754342] [doi: 10.1111/clr.12772]

10. Saaby M, Karring E, Schou S, Isidor F. Factors influencing severity of peri-implantitis. Clin Oral Implants Res. 2016 Jan;27(1):7-12. [Medline: 25395333] [doi: 10.1111/clr.12505]

11. Derks J, Schaller D, Håkansson J, Wennström JL, Tomasi C, Berglundh T. Effectiveness of Implant Therapy Analyzed in a Swedish Population: Prevalence of Peri-implantitis. J Dent Res. 2016 Jan;95(1):43-9. [Medline: 26701919] [doi: 10.1177/0022034515608832]

12. Schulte W. Implants and the periodontium. Int Dent J. 1995 Feb;45(1):16-26. [Medline: 7607740]

13. Sekine H, Komiyama Y, Potta H, Yoshida K. Mobility characteristics and tactile sensitivity of osseointegrated fixturesupporting systems. In: van Steenberghe D, Albrektsson T, Brånemark PI, Henry PJ, Holt R, Liden G, editors. Tissue integration in oral and maxillofacial reconstruction. Amsterdam: Excerpta Medica; 1986. p. 326-32.

14. Frost HM. Bone's mechanostat: a 2003 update. Anat Rec A Discov Mol Cell Evol Biol. 2003 Dec;275(2):1081-101. Review. [Medline: 14613308] [doi: 10.1002/ar.a.10119]

15. Sakka S, Baroudi K, Nassani MZ. Factors associated with early and late failure of dental implants. J Investig Clin Dent. 2012 Nov;3(4):258-61. [Medline: 22927130] [doi: 10.1111/j.2041-1626.2012.00162.x]

16. Moher D, Liberati A, Tetzlaff J, Altman DG; PRISMA Group. Preferred reporting items for systematic reviews and metaanalyses: the PRISMA statement. Int J Surg. 2010;8(5):336-41. Epub 2010 Feb 18. Erratum in: Int J Surg. $2010 ; 8(8): 658$. [Medline: 20171303] [doi: 10.1016/j.ijsu.2010.02.007]

17. Higgins JPT, Altman DG, Sterne JAC. Chapter 8: assessing risk of bias in included studies. In: Higgins JPT, Green S, editors. Cochrane handbook for systematic reviews of interventions version 5.1.0 (updated March 2011). The Cochrane Collaboration. 2011. [URL: http://handbook.cochrane.org/]

18. Jimbo R, Halldin A, Janda M, Wennerberg A, Vandeweghe S. Vertical fracture and marginal bone loss of internalconnection implants: a finite element analysis. Int J Oral Maxillofac Implants. 2013 Jul-Aug;28(4):e171-6. [Medline: 23869374] [doi: 10.11607/jomi.3052]

19. Aguirrebeitia J, Abasolo M, Vallejo J, Ansola R. Dental implants with conical implant-abutment interface: influence of the conical angle difference on the mechanical behavior of the implant. Int J Oral Maxillofac Implants. 2013 MarApr;28(2):e72-82. [Medline: 23527371] [doi: 10.11607/jomi.2775]

20. Bouazza-Juanes K, Martínez-González A, Peiró G, Ródenas JJ, López-Mollá MV. Effect of platform switching on the peri-implant bone: A finite element study. J Clin Exp Dent. 2015 Oct 1;7(4):e483-8. [Medline: 26535094] [PMC free article: 4628802] [doi: 10.4317/jced.52539]

21. Sahabi M, Adibrad M, Mirhashemi FS, Habibzadeh S. Biomechanical effects of platform switching in two different implant systems: a three-dimensional finite element analysis. J Dent (Tehran). 2013 May;10(4):338-50. Epub 2013 May 31. [Medline: 24396353] [PMC free article: 3875508]

22. Paul S, Padmanabhan TV, Swarup S. Comparison of strain generated in bone by "platform-switched" and "non-platformswitched" implants with straight and angulated abutments under vertical and angulated load: a finite element analysis study. Indian J Dent Res. 2013 Jan-Feb;24(1):8-13. [Medline: 23852226] [doi: 10.4103/0970-9290.114913]

23. Martini AP, Freitas AC Jr, Rocha EP, de Almeida EO, Anchieta RB, Kina S, Fasolo GB. Straight and angulated abutments in platform switching: influence of loading on bone stress by three-dimensional finite element analysis. J Craniofac Surg. 2012 Mar;23(2):415-8. [Medline: 22421854] [doi: 10.1097/SCS.0b013e31824b9c17]

24. Vidya Bhat S, Premkumar P, Kamalakanth Shenoy K. Stress Distribution Around Single Short Dental Implants: A Finite Element Study. J Indian Prosthodont Soc. 2014 Dec;14(Suppl 1):161-7.. [Medline: 26199508] [PMC free article: 4502034] [doi: 10.1007/s13191-014-0390-y]

25. I-Chiang C, Shyh-Yuan L, Ming-Chang W, Sun CW, Jiang CP. Finite element modelling of implant designs and cortical bone thickness on stress distribution in maxillary type IV bone. Comput Methods Biomech Biomed Engin. 2014 Apr;17(5):516-26. [Medline: 22746374] [doi: 10.1080/10255842.2012.697556]

26. Santiago Junior JF, Pellizzer EP, Verri FR, de Carvalho PS. Stress analysis in bone tissue around single implants with different diameters and veneering materials: a 3-D finite element study. Mater Sci Eng C Mater Biol Appl. 2013 Dec 1;33(8):4700-14. [Medline: 24094178] [doi: 10.1016/i.msec.2013.07.027]

27. Savadi RC, Agarwal J, Agarwal RS, Rangarajan V. Influence of Implant Surface Topography and Loading Condition on Stress Distribution in Bone Around Implants: A Comparative 3D FEA. J Indian Prosthodont Soc. 2011 Dec;11(4):221-31. [Medline: 23204731] [PMC free article: 3205178] [doi: 10.1007/s13191-011-0105-6] 
28. Chou IC, Lee SY, Jiang CP. Effects of implant neck design on primary stability and overload in a type IV mandibular bone. Int J Numer Method Biomed Eng. 2014 Nov;30(11):1223-37. [Medline: 24799197] [doi: 10.1002/cnm.2653]

29. Demenko V, Linetsky I, Nesvit V, Linetska L, Shevchenko A. FE study of bone quality effect on load-carrying ability of dental implants. Comput Methods Biomech Biomed Engin. 2014;17(16):1751-61. [Medline: 23527468] [doi: 10.1080/10255842.2013.766173]

30. Bölükbaşı N, Yeniyol S. Number and localization of the implants for the fixed prosthetic reconstructions: on the strain in the anterior maxillary region. Med Eng Phys. 2015 Apr;37(4):431-45. [Medline: 25765190] [doi: 10.1016/j.medengphy.2015.02.004]

31. Ormianer Z, Palti A, Demiralp B, Heller G, Lewinstein I, Khayat PG. Implant-supported first molar restorations: correlation of finite element analysis with clinical outcomes. Int J Oral Maxillofac Implants. 2012 Jan-Feb;27(1):e1-12. [Medline: 22299100]

32. Laster Z, Weissberg I, Kablan F. Biomechanics and peri-implantitis: The effect of a subcrestal wing-thread to decrease alveolar crestal bone strain. theory, finite element analysis, and clinical application. Int J Oral Maxillofac Implants. 2014 Mar-Apr;29(2):e265-71. [Medline: 24683590] [doi: 10.11607/jomi.te63]

33. Xia H, Wang M, Ma L, Zhou Y, Li Z, Wang Y. The effect of platform switching on stress in peri-implant bone in a condition of marginal bone resorption: a three-dimensional finite element analysis. Int J Oral Maxillofac Implants. 2013 May-Jun;28(3):e122-7. [Medline: 23748330] [doi: 10.11607/jomi.2965]

34. Sotto-Maior BS, Senna PM, da Silva WJ, Rocha EP, Del Bel Cury AA. Influence of crown-to-implant ratio, retention system, restorative material, and occlusal loading on stress concentrations in single short implants. Int J Oral Maxillofac Implants. 2012 May-Jun;27(3):e13-8. [Medline: 22616067]

35. Wakabayashi N, Ona M, Suzuki T, Igarashi Y. Nonlinear finite element analyses: advances and challenges in dental applications. J Dent. 2008 Jul;36(7):463-71. [Medline: 18455859] [doi: 10.1016/j.jdent.2008.03.010]

36. Romeed SA, Malik R, Dunne SM. Marginal bone loss influence on the biomechanics of single implant crowns. J Craniofac Surg. 2013 Jul;24(4):1459-65. [Medline: 23851832] [doi: 10.1097/SCS.0b013e3182902db0]

37. Boldt J, Knapp W, Proff P, Rottner K, Richter EJ. Measurement of tooth and implant mobility under physiological loading conditions. Ann Anat. 2012 Mar 20;194(2):185-9. [Medline: 22074678] [doi: 10.1016/j.aanat.2011.09.007]

38. Arun Kumar G, Mahesh B, George D. Three dimensional finite element analysis of stress distribution around implant with straight and angled abutments in different bone qualities. J Indian Prosthodont Soc. 2013 Dec;13(4):466-72. [Medline: 24431777] [PMC free article: 3792315] [doi: 10.1007/s13191-012-0242-6]

39. Zanardi PR, Stegun RC, Sesma N, Costa B, Shibli JA, Laganá DC. Stress Distribution Around Dental Implants Placed at Different Depths. J Craniofac Surg. 2015 Oct;26(7):2163-6. [Medline: 26468803] [doi: 10.1097/SCS.0000000000002119]

40. Mumcu E, Bilhan H, Cekici A. Marginal bone loss around implants supporting fixed restorations. J Oral Implantol. 2011 Oct;37(5):549-58. [Medline: 20712440] [doi: 10.1563/AAID-JOI-D-10-00018]

41. Romanos GE, Gupta B, Gaertner K, Nentwig GH. Distal cantilever in full-arch prostheses and immediate loading: a retrospective clinical study. Int J Oral Maxillofac Implants. 2014 Mar-Apr;29(2):427-31. [Medline: 24683570] [doi: $10.11607 /$ jomi.3243]

42. Lee DW, Lee DW, Park KH, Moon IS. The effects of off-axial loading on periimplant marginal bone loss in a single implant. J Prosthet Dent. 2014 Sep;112(3):501-7. [Medline: 24721506] [doi: 10.1016/j.prosdent.2014.02.004]

43. Urdaneta RA, Seemann R, Dragan IF, Lubelski W, Leary J, Chuang SK. A retrospective radiographic study on the effect of natural tooth-implant proximity and an introduction to the concept of a bone-loading platform switch. Int $\mathrm{J}$ Oral Maxillofac Implants. 2014 Nov-Dec;29(6):1412-24. [Medline: 25397804]

44. Malchiodi L, Cucchi A, Ghensi P, Consonni D, Nocini PF. Influence of crown-implant ratio on implant success rates and crestal bone levels: a 36-month follow-up prospective study. Clin Oral Implants Res. 2014 Feb;25(2):240-51. [Medline: 23402530] [doi: 10.1111/clr.12105]

45. Ojeda J, Martínez-Reina J, García-Aznar JM, Domínguez J, Doblaré M. Numerical simulation of bone remodelling around dental implants. Proc Inst Mech Eng H. 2011 Sep;225(9):897-906. [Medline:22070027] [doi: 10.1177/0954411911410165]

46. Valderrama P, Bornstein MM, Jones AA, Wilson TG, Higginbottom FL, Cochran DL. Effects of implant design on marginal bone changes around early loaded, chemically modified, sandblasted Acid-etched-surfaced implants: a histologic analysis in dogs. J Periodontol. 2011 Jul;82(7):1025-34. [Medline: 21142981] [doi: 10.1902/jop.2010.100491]

47. Kan JP, Judge RB, Palamara JE. In vitro bone strain analysis of implant following occlusal overload. Clin Oral Implants Res. 2014 Feb;25(2):e73-82. [Medline: 23067316] [doi: 10.1111/clr.12059]

48. Harel N, Eshkol-Yogev I, Piek D, Livne S, Lavi D, Ormianer Z. Bone microstrain values of 1-piece and 2-piece implants subjected to mechanical loading. Implant Dent. 2013 Jun;22(3):277-81. [Medline: 23615662] [doi: 10.1097/ID.0b013e3182926199]

49. Meleo D, Baggi L, Di Girolamo M, Di Carlo F, Pecci R, Bedini R. Fixture-abutment connection surface and micro-gap measurements by 3D micro-tomographic technique analysis. Ann Ist Super Sanita. 2012;48(1):53-8. [Medline: 22456016] [doi: $10.4415 / \mathrm{ANN} 12 \quad 01 \quad 09]$

50. Abduo J, Judge RB. Implications of implant framework misfit: a systematic review of biomechanical sequelae. Int J Oral Maxillofac Implants. 2014 May-Jun;29(3):608-21. [Medline: 24818199] [doi: 10.11607/jomi.3418] 
51. Caetano CR, Mesquita MF, Consani RL, Correr-Sobrinho L, Dos Santos MB. Overdenture retaining bar stress distribution: a finite-element analysis. Acta Odontol Scand. 2015 May;73(4):274-9. [Medline: 25645607] [doi: 10.3109/00016357.2014.923111]

52. Farina AP, Spazzin AO, Pantoja JM, Consani RL, Mesquita MF. An in vitro comparison of joint stability of implantsupported fixed prosthetic suprastructures retained with different prosthetic screws and levels of fit under masticatory simulation conditions. Int J Oral Maxillofac Implants. 2012 Jul-Aug;27(4):833-8. [Medline: 22848885]

53. Magne P, Silva M, Oderich E, Boff LL, Enciso R. Damping behavior of implant-supported restorations. Clin Oral Implants Res. 2013 Feb;24(2):143-8. [Medline: 22092518] [doi: 10.1111/j.1600-0501.2011.02311.x]

54. Andreasi Bassi M, Bedini R, Pecci R, Ioppolo P, Lauritano D, Carinci F. Mechanical properties of resin glass fiberreinforced abutment in comparison to titanium abutment. J Indian Soc Periodontol. 2015 May-Jun;19(3):273-8. [Medline: 26229266] [PMC free article: 4520110] [doi: 10.4103/0972-124X.154184]

55. Sheikhhassani R, Anvari P, Taei S, Sheikhhassani Y. Potential use of a polycarbonate-urethane matrix reinforced with polyethylene fibers for shock-absorbing dental implants. Med Hypotheses. 2015 Sep;85(3):241-4. [Medline: 26008614] [doi: 10.1016/j.mehy.2015.05.003]

56. Urdaneta RA, Leary J, Panetta KM, Chuang SK. The effect of opposing structures, natural teeth vs. implants on crestal bone levels surrounding single-tooth implants. Clin Oral Implants Res. 2014 Feb;25(2):e179-88. [Medline: 23278549] [doi: $10.1111 / \mathrm{clr} .12087]$

57. Urdaneta RA, Leary J, Lubelski W, Emanuel KM, Chuang SK. The effect of implant size $5 \times 8 \mathrm{~mm}$ on $\mathrm{crestal}$ bone levels around single-tooth implants. J Periodontol. 2012 Oct;83(10):1235-44. [Medline: 22309172] [doi: 10.1902/jop.2012.110299]

58. Fu JH, Hsu YT, Wang HL. Identifying occlusal overload and how to deal with it to avoid marginal bone loss around implants. Eur J Oral Implantol. 2012;5 Suppl:S91-103. [Medline: 22834398]

59. Nagasawa M, Takano R, Maeda T, Uoshima K. Observation of the bone surrounding an overloaded implant in a novel rat model. Int J Oral Maxillofac Implants. 2013 Jan-Feb;28(1):109-16. [Medline: 23377055] [doi: 10.11607/jomi.2388]

60. He J, Zhao B, Deng C, Shang D, Zhang C. Assessment of implant cumulative survival rates in sites with different bone density and related prognostic factors: an 8-year retrospective study of 2,684 implants. Int J Oral Maxillofac Implants. 2015 Mar-Apr;30(2):360-71. [Medline: 25830396] [doi: 10.11607/jomi.3580]

61. Isidor F. Histological evaluation of peri-implant bone at implants subjected to occlusal overload or plaque accumulation. Clin Oral Implants Res. 1997 Feb;8(1):1-9. [Medline: 9586450] [doi: 10.1111/j.1600-0501.1997.tb00001.x]

62. Pellegrini G, Canullo L, Dellavia C. Histological features of peri-implant bone subjected to overload. Ann Anat. 2016 Jul;206:57-63. [Medline: 25842362] [doi: 10.1016/j.aanat.2015.02.011]

63. Alvarez-Arenal A, Brizuela-Velasco A, DeLlanos-Lanchares H, Gonzalez-Gonzalez I. Should oral implants be splinted in a mandibular implant-supported fixed complete denture? A 3-dimensional-model finite element analysis. J Prosthet Dent. 2014 Sep;112(3):508-14. [Medline: 24560983] [doi: 10.1016/j.prosdent.2013.12.004]

64. Kurniawan D, Nor FM, Lee HY, Lim JY. Finite element analysis of bone-implant biomechanics: refinement through featuring various osseointegration conditions. Int J Oral Maxillofac Surg. 2012 Sep;41(9):1090-6. [Medline: 22260789] [doi: 10.1016/j.ijom.2011.12.026]

\section{To cite this article:}

Maminskas J, Puisys A, Kuoppala R, Raustia A, Juodzbalys G.

The Prosthetic Influence and Biomechanics on Peri-Implant Strain: a Systematic Literature Review of Finite Element Studies J Oral Maxillofac Res 2016;7(3):e4

URL: http://www.ejomr.org/JOMR/archives/2016/3/e4/v7n3e4.pdf

doi: $10.5037 /$ jomr.2016.7304

Copyright (C) Maminskas J, Puisys A, Kuoppala R, Raustia A, Juodzbalys G. Published in the JOURNAL OF ORAL \& MAXILLOFACIAL RESEARCH (http://www.ejomr.org), 9 September 2016.

This is an open-access article, first published in the JOURNAL OF ORAL \& MAXILLOFACIAL RESEARCH, distributed under the terms of the Creative Commons Attribution-Noncommercial-No Derivative Works 3.0 Unported License, which permits unrestricted non-commercial use, distribution, and reproduction in any medium, provided the original work and is properly cited. The copyright, license information and link to the original publication on (http://www.ejomr.org) must be included. 